\title{
The adventure of an adventure videogame in French
}

\author{
Juan Manuel Muñoz González \\ juan.manuel@uco.es \\ University of Córdoba, Spain \\ Carmen de Castro Castro \\ ff1castr@uco.es \\ University of Córdoba, Spain
}

Ana Isabel Brazo Millán

abmillan@uco.es

University of Córdoba, Spain

\begin{abstract}
With the understanding that videogames have become a powerful resource not only for entertainment but also as an educational resource for foreign language teaching today, the objective of this study was to examine the use of the videogame Broken Sword for the teaching of French as a foreign language in a higher education setting. To assess the suitability of the video game as a foreign language teaching tool, a quantitative methodology based on a 22-item ad hoc questionnaire was used, through which we collected the assessment of the students. Despite the expectations and the high degree of participation and cooperation of the students surveyed, the results revealed an attitude of indifference regarding the videogame's contributions to language learning. We considered the results to be very positive, as for many of the students this exercise was not only a test with a language that they did not master yet, but also had technical difficulties that they had to overcome. The challenge of this experience invites us to continue working with new videogames titles and to improve our future methodological interventions.
\end{abstract}

\section{Keywords}

French; videogames; foreign language acquisition; initial teaching training; higher education 


\section{Introduction}

In the last few years, great advances have been made on the novel practice of using videogames as a tool for learning a foreign language (FL), which in our case, is French. The empirical study conducted by Alabay (2015) not only shows that the experience of using a videogame in class, and everything related to it are pertinent, but also, the results pointed to the increasingly positive welcome of the videogame in the classroom. The study showed that more than nine out of ten students use the mobile phone to play, and that $86.9 \%$ of them considered that lexical competence was the most relevant for playing. Likewise, the study concluded that for $95.4 \%$ of the students polled, the use of the videogame could be pertinent a priori.

Also, as compared to other types of technological inputs, videogames have virtues that are based on their game characteristics and the motivation they are able to create, as discussed in the literature specific to the area of study:

[...] that videogames are fun and highly entertaining because they are task-based. They stimulate cooperation and competition by focusing on the achievement of goals, they provide players with real-time feedback on their failure or success and encourage players to explore, experiment and take risks in problem solving. (Berns, González-Pardo and Camacho, 2011, p. 4)

The attractiveness of this new tool for learning has provided optimism to the area of didactic research, as shown by numerous national and international studies (García-Carbonell and Watts, 2007; García-Carbonell, Andreu-Andrés and Watts, 2014; del Moral and Fernández, 2015), which have established a clear nexus between the didactic focus and the use of videogames. These studies have also analyzed, for example, the relationship between the communicative focus and the use of a simulated environment in the videogames, insisting on what is adequate for the use of this tool for the current focus of learning of a FL. On their part, Berns, González-Pardo and Camacho (2013) have focused their research on the use of 3D videogames, showing that this new context increases the interaction and the use of language, thereby improving the linguistic competence of the user. Lastly, the work by Calvo-Ferrer and Belda-Medina (2015) is underlined, which studied the acquisition of specialized terminology, highlighting that the users were more motivated and satisfied with his or her learning thanks to the immersive character and the feedback offered by the videogames.

The fact that it is a game provides, undoubtedly, new emotional situations that can be explored.

To this respect, Klein (2013), points to the paradox of continuous exposure to the failure and stress produced from playing a game in a foreign language, and how this risk is, however, what greatly motivates the player. Therefore, failure is only momentary, personal and private, as opposed to other learning situations of a F.L., thereby favoring continuous play.

But, how have videogames been introduced as tools for learning? Two lines have been clearly distinguished in their design, development and use in teaching: the first has been to extend the activities online, thus becoming more interactive and game-like, up to the creation of videogames with characteristics and incentives similar to commercial games (Ricoy and Ameneiros, 2016). The results are "serious games", which, although having good design qualities and correct functionality, fall short of commercial games, created by powerful businesses with a great amount of resources. In these last few years, the degree of motivation they entailed as compared to other activities, and conclusive results, have not been found, as shown in the works by Wouters, van Nimwegen, van Oostendorp and van der Spek (2013) as well as de Castro, Muñoz and Brazo (2018). The second is the use of specific commercial games, either through their modification (game modding) or through middleware or metaverses, or using them in their original version, although in an educational context, as in the present research.

A commercial videogame is, in the end, an authentic document, and with respect to this, numerous 
studies can be mentioned that from the 80 's have analyzed their treatment in the classroom (Besse, 1984; 1987; Beacco, 1988; 2000; Bérard, 1991; Gilmore, 2007). In these studies, it was shown how the authenticity of the document was subverted when it was "didacticized":

Removed from its original context, the document loses part of its original communicative functionality. Moreover, once this type of document is modified for didactic aims, for example, adapted, cut, summarized, expunged, perhaps re-written and other abrupt transformations for making it more accessible to learners, it becomes a didactized document (Quivy and Tardieu 2002, p.100).

This process is also applicable to the commercial videogame that has to be subjected to conditions of teaching and evaluation, and therefore, loses some of its more attractive characteristics: the freedom to play or not, the intimate act of playing, the independence from academic evaluations, etc. In this sense, the following questions were asked: if the videogame was a part of the activities of the school curriculum, prepared and used in class, would the students consider it a highly motivational activity, even if the game would lose its main game characteristics? And, on the contrary, if it was a voluntary activity, we would not know if it responded to the real needs and interests of the students, and therefore, if they would play or not. Ultimately, an intermediate solution was proposed.

\section{Description of the study}

When starting the project, which was focused on the use of the videogame in the French as F.L. class with adult students, the best conditions were sought for not "didacticizing" the game, so that no preparation or simulation sessions were conducted, as it was assumed that the students, as indicated by Rama, Black, van Es and Warsrchauer (2012), would show the appropriate interest and technical domain. The following statement has been found related to this: given the important role that gaming currently plays in the everyday lives of adolescents and young adults in developed countries, this spike in interest is not surprising (Godwing-Jones, 2014, p.9).

Also, as indicated by Calvo-Ferrer and Belda-Medina (2015), it was believed that most of the students were fluent in the language of the videogames, but an objective study had to be conducted in order to obtain reliable data.

Currently, in our opinion, the learning of a FL has to exceed what is taught by the teacher or the current methods utilized, although these are still essential. Despite the attempt of the publishers to continue selling compact methods, the truth is that the use of the internet allows the teachers and students to experience customized and personal learning, as it provides every type of audio, visual and written tools, which they could and should utilize. Therefore, the videogame, as the novel, should not be used solely in the classroom, but should be enjoyed outside of it. And perhaps, just as a reader of a written work, the player should be able to play without any further clarification or pre-requisite, as the videogames have been created so that any player can use them, whether they have previous experience with it or not.

It is without a doubt not easy to find a game that is adequate for the learning of French as a foreign language, as most of the videogames use English as the main language, and only some of them have versions in other languages. This limited our choice of games, although the classic Broken Sword: The Shadow of the Templars game was finally chosen, a point and click graphical adventure videogame with a high visual quality using comic book-like art. The French version of the audio is good, just as the subtitles, and it is narrated in third person. However, from the point of view of language, there is no interaction with the player, who is limited to the oral comprehension of the narration and the dialogues, as well as the written comprehension of the 
subtitles. This videogame has an attractive detective/investigative argument where the characters, a French girl and an American journalist, begin an investigation that conceals conspiracies, cults and murders, all of it revolving around the Knights Templar. This adventure brings them to different locations around the world, such as Paris, Ireland, Syria or Spain.

The game consists on solving a series of puzzles, searching for objects, making them interact with other objects or characters. To this end, there are texts and puzzles that also demand a good writing comprehension. As a source of help, the actions taken are gathered in a diary.

Thus, from the technical point of view, it is a well-developed game that is easy to use, and its mechanics allows for a total immersion into history. In its selection, it was believed that the game could be known to the students, and that its classic design would not excessively distract from its comprehension.

On the other hand, the development of this study entailed the choosing of various student groups in the 2016/2017 academic year, enrolled in the course "Language CIII French" and "Language CIV French" from the Translation and Interpretation Degree, as well as from the course "Foreign Language (French) for Primary School teachers" from the Primary Education Teacher Degree.

The implementation of this study experienced many difficulties and had some surprises, such as the use of the Steam platform, used for the acquisition of licenses, which resulted in delays and inconveniences due to the non-familiarization of the students with digital distribution platforms, communications and multi-player services. According to the comments received during the technical sessions, it could be discerned that our assumptions were not correct, as not too many of the students were videogame players. To this end, when proposing a French novel to improve the reading comprehension and the vocabulary, it should be taken into account if the students will have difficulties in the reading, enjoy the text, or if they will obtain the benefits that were intended with its use.

\section{Objetives}

The study presented addressed various objectives that are described below:

1. To describe the opinions of the third-year students from the Primary Education Degree, as well as the opinions from first year students enrolled in the Translation and Interpretation Degree from the University of Cordoba, with respect to the contributions of the videogame Broken Sword in the learning of French as a foreign language.

2. To analyze the differences in the 3 dimensions that comprised the Questionnaire on the use of videogames for the learning of French in higher education and according to sex, age, degree, devices used for playing the game and the manner of playing it.

3. To observe the existence or not of correlations between the different dimensions of the questionnaire.

4. To establish models to predict the evaluation of the videogame depending on the student/ player's profile. 


\section{Methodology}

\section{a. Sample and Participants}

The sample selection was conducted by using a non-probabilistic or convenience sampling procedure (Cuenca and Lozano, 2016), as the learning methodology developed in the classroom, as well as the application of the questionnaire, were only conducted with the groups of students to whom the teachers in the project gave classes during the 2016-2017 academic year.

The sample was composed by 15 students enrolled in the 3rd year of the Primary Education Degree (19\%), and 64 students from the Translation and Interpretation Degree (81\%). Their ages ranged from 18 to 26 years of age, with the highest percentage found in the $18-20$ age range $(79.7 \% n=$ 63). As for the sex of the students, $77.2 \%$ of the sample was composed by female students ( $n=$ 61).

As for the relationship between age and sex of the students, more than half of the students (79.7\%) were aged $18-20$ years old, with $76.2 \%$ being female and $23.8 \%$ male. Also, $15.2 \%$ of them were aged between $21-23$ years old, of which $91.7 \%$ were female and $8.3 \%$ male. Lastly, $5.1 \%$ were aged between $24-26$ years old, of which $50 \%$ were male and $50 \%$ female.

\section{b. Data collection instrument}

The questionnaire used for this study, named Questionnaire on the use of the videogames for the learning of French in higher education was composed by 22 items. The validation and reliability of the instrument was measured and corroborated with different statistical analysis. For the validity of the construct, an exploratory factorial analysis was conducted, with Pearson's correlation (Lorenzo-Seva and Van Ginkel, 2016), as the variance had a normal distribution, shown by the Kolmogorov-Smirnov test $(p=0.100)$, together with a Maximum Likelihood process of extraction of common factors, taking into account a Weighted Oblimin rotation procedure (Lorenzo-Seva, 2000), whose Kaiser-Meyer-Olkin (KMO) index was 0.84 and Bartlett's sphericity test was $p=0.000$. The result of the extraction of principal components showed the existence of three factors where the total variance explained was $62.46 \%$, revealing an appropriate equilibrium between the components of the instrument, which were representative of the theoretical model (see Table 1). The measurement of the reliability of the instrument was conducted with an internal consistency focus (Merino-Soto, 2016), obtaining a Cronbach's Alpha of 0.89 , reflecting a high reliability of the items of the questionnaire. On the other hand, the matrix of rotated components showed that there were three factors that contributed with explanations of the construct studied: 1 . Profile of the student/player $(a=.89) ; 2$. Evaluation of the videogame for the learning of French $(a=.86) ; 3$. Quality of the audio and subtitles of the videogame $(a=.81)$.

\begin{tabular}{|c|c|l|l|}
\hline & $\begin{array}{c}\text { Factor 1. Profile of } \\
\text { student/player }\end{array}$ & $\begin{array}{l}\text { Factor 2. Evaluation of the } \\
\text { videogame for the learning of } \\
\text { French }\end{array}$ & $\begin{array}{l}\text { Factor 3. Quality of } \\
\text { the audio/subtitles }\end{array}$ \\
\hline Item1 & .796 & & \\
\hline Item2 & .871 & & \\
\hline Item3 & .828 & & \\
\hline Item4 & .829 & & \\
\hline Item5 & .839 & & \\
\hline Item6 & & & \\
\hline
\end{tabular}




\begin{tabular}{|c|c|c|}
\hline Item7 & .566 & \\
\hline Item8 & .577 & \\
\hline Item9 & .780 & \\
\hline Item 10 & .766 & \\
\hline Item 11 & .636 & \\
\hline Item 12 & .678 & \\
\hline Item 13 & .434 & \\
\hline Item 14 & .421 & \\
\hline Item 15 & .490 & \\
\hline Item 16 & .667 & \\
\hline Item 17 & .584 & \\
\hline Item 18 & .688 & \\
\hline Item 19 & & .749 \\
\hline Item 20 & & .609 \\
\hline Item 21 & & .795 \\
\hline Item 22 & & .746 \\
\hline
\end{tabular}

Table 1. Matrix of Rotated Components in the Exploratory Factorial Analysis

Source: Author created

The 22 items measured with a 5-point Likert scale ( $1=$ completely disagree to $5=$ completely agree) were used to ask the students their opinion about the use of the Broken Sword videogame for the learning of French as a foreign language. Also, the students were asked to answer direct questions related to their personal data (sex and age), academics (Degree), as well as questions related to devices used for the playing videogames and the manner of playing as well.

\section{c. Procedure}

The instrument used was provided to the students when the learning activity based on the use of the Broken Sword videogame for the learning of French was concluded, with 30 minutes given for its completion. The researchers of the study were responsible for applying the methodology, as well as collecting the data from the students enrolled in both degrees.

\section{d. Data analysis}

The analysis conducted to provide answers to the objectives described above, were the following:

- In first place, a descriptive analysis was conducted of the 22 variables that comprised the questionnaire, through the statistical measurements of mean and standard deviation.

- In second place, a descriptive analysis of the 3 dimensions of the questionnaire was 
conducted, by calculating the frequency distribution, the mean and standard deviations.

- In third place, different analyses of variance were conducted to verify if there was a relationship between the dimensions of the questionnaire and the independent variables sex, age, degree, time and playing mode. For this, a Student's $t$ test and ANOVA were performed, using the statistical package SPSS 23.

- In fourth place, the relationship between the dimensions that comprised the questionnaire were verified with bivariate correlations.

- Lastly, linear regressions were performed to predict the evaluation of the Broken Sword videogame for the learning of French depending on the profile of the student/player.

\section{Results}

In first place, the descriptive results of the 22 items that comprised the questionnaire used in the present study are shown. Table 2 shows the means and standard deviations (SD) of the items that comprised the questionnaire on the use of the Broken Sword videogame for the teaching of French in Higher Education:

\begin{tabular}{|c|c|c|c|}
\hline Dimensions & Item & M & $S D$ \\
\hline \multirow{6}{*}{$\begin{array}{l}\text { Dimension 1: Profile of } \\
\text { the student/player } \\
\text { ( } 6 \text { items) }\end{array}$} & 1. I like to play videogames & 2.89 & 1.43 \\
\hline & 2. I habitually play a videogame & 2.14 & 1.37 \\
\hline & 3. I have played many videogames & 2.52 & 1.38 \\
\hline & $\begin{array}{l}\text { 4. Most of the videogames I play with is in } \\
\text { multiplayer mode }\end{array}$ & 2.09 & 1.24 \\
\hline & $\begin{array}{l}\text { 5. I chat with other players during the game, for } \\
\text { example, with a microphone and headphones }\end{array}$ & 1.78 & 1.28 \\
\hline & $\begin{array}{l}\text { 6. I like to be part of videogame communities of the } \\
\text { videogames I play with }\end{array}$ & 1.91 & 1.28 \\
\hline \multirow{10}{*}{$\begin{array}{l}\text { Dimension 2: } \\
\text { Evaluation of the } \\
\text { Broken Sword game for } \\
\text { the learning of French } \\
\text { (12 items) }\end{array}$} & 7. The game is entertaining & 3.41 & 0.98 \\
\hline & 8. The game focuses all my attention & 3.46 & 1.06 \\
\hline & 9. The game is intuitive & 3.24 & 1.26 \\
\hline & 10. The game is simple & 2.71 & 1.00 \\
\hline & $\begin{array}{l}\text { 11. The game has a high degree of interaction } \\
\text { (game/user) }\end{array}$ & 3.43 & 1.05 \\
\hline & 12. The game has a clear objective & 3.68 & 1.09 \\
\hline & 13. The game improves your oral comprehension & 3.42 & 1.15 \\
\hline & 14. The game improves your written comprehension & 3.34 & 0.99 \\
\hline & 15. The game has broadened your vocabulary & 3.53 & 0.96 \\
\hline & $\begin{array}{l}\text { 16. The game allows one to learn constantly during } \\
\text { the hours dedicated to playing }\end{array}$ & 3.62 & 0.99 \\
\hline
\end{tabular}




\begin{tabular}{|l|l|l|l|}
\cline { 2 - 4 } & $\begin{array}{l}\text { 17. The games has different degrees of linguistic } \\
\text { difficulty }\end{array}$ & 3.43 & 0.92 \\
\cline { 2 - 4 } & 18. I have found degrees of difficulty in the game & 3.43 & 1.12 \\
\hline $\begin{array}{l}\text { Dimension 3: } \\
\text { Evaluation of the quality } \\
\text { of the audio/subtitles (4 } \\
\text { items) }\end{array}$ & 19. The subtitles of the game have a high quality & 3.97 & 1.03 \\
\cline { 2 - 4 } & 20. The subtitles are fundamental for playing & 3.81 & 1.20 \\
\cline { 2 - 4 } & 21. The quality of the game's audio is good & 3.89 & 1.04 \\
\cline { 2 - 4 } & 22. The vocalization of the speakers is correct & 3.90 & 1.05 \\
\hline
\end{tabular}

Table 2. Distribution of the Frequencies of the Items Found in the Questionnaire on the Use of the Broken Sword Videogame for the Teaching of French in Higher Education

Source: Author created

Next, the results are presented grouped as a function of the 3 dimensions found in the questionnaire. In this sense, the descriptive data of each of the dimensions are shown, as well as the existence of statistically significant differences, taking into account the independent variables of the study (sex, age, degree, device and playing mode). Lastly, the existing relationship between the dimensions that comprised the questionnaire is presented, as well as the establishing of a predictive model of the student's evaluations with respect to the contributions of the videogame for the learning of French as a function of the student/player's profile.

\section{a. Profile of the student/player}

In this dimension, 6 items were grouped that alluded to the opinions of the students related to their preferences, dedication, quantity and playing modes, as related to the area of videogames.

In the results obtained in this dimension, it was observed that the students had an opinion that was partially in disagreement, as related to the profile student/player $(\mu=2.22 ; \sigma=1.08)$.

As for the differences established by sex in relation of the profile of the student/player, Student's $t$ test for independent samples showed that there were statistically significant differences as a function of the student's gender with respect to the profile of the student/player $(T=3.131, p$ $=.002$ ). Thus, the mean of the men was higher than the women's, as related to the profile of the student/player (2.88 vs 2.08 ).

As for the differences established by the student's degree, as related to the profile of the student/ player, the same test showed that there were no statistically significant differences.

To determine the influence of age, the gaming device and the playing mode on the results, a multiple comparison of the means was performed with an ANOVA. The results obtained showed that there were no statistically significant differences between age and the profile of the student/ player.

As for the relationship between the gaming device employed by the student and the profile of the student/player, the analysis showed that there were statistically significant differences between the device used to play the game and the profile of the student/player $[F(3,75)=14.535 ; p=.000]$. The post hoc multiple comparisons test with Tukey's test allowed us to determine with which devices the differences in means were found, with the users that used various gaming devices being the ones who were partially in agreement with respect to the profile student/player as compared to those who used the videogame console and the PC/Mac, respectively ( $\mu=4.25$ vs $\mu=$ 3.73 and $\mu=1.95)$. 
Lastly, referring to the playing mode, the same test was performed to compare the means, with the results showing that there were no statistically significant differences.

\section{b. Evaluation of the Broken Sword game for the learning of French}

This dimension was composed by 12 items which were used to evaluate the use of the Broken Sword videogame for the learning of French as a foreign language. More specifically, these are the characteristics of the game (environment, degree of difficulty, degree of interaction, etc.) and the learning of French (oral and written comprehension, lexical enrichment, degree of difficulty, etc.).

In the results obtained in this dimension, it was observed that the students had an evaluation of indifference with respect to the dimension "Evaluation of the Broken Sword videogame for the learning of French $(\mu=3.39 ; \sigma=0.66)$.

On the other hand, the Student's $t$ test performed to identify possible differences in relation to the student's gender as for the evaluation of the videogame Broken Sword for the learning of French as a foreign language, showed that there were no statistically significant differences.

With respect to the differences established by the degree in relation to the evaluation of the Broken Sword videogame for the learning of French as a foreign language, the same test showed that there were no statistically significant differences either.

On the other hand, the ANOVA performed to verify the existence of significant differences between age, the device utilized to play and the playing mode, as related to the evaluation of the Broken Sword videogame for the learning of French as foreign language, showed that there were no statistically significant differences related to age, with the same results found for the influence of the device utilized to play the game.

Lastly, for the playing mode, the same test was conducted to compare the means. The test pointed to the inexistence of statistically significant differences with respect to the evaluation of the Broken Sword videogame in the learning of French as a foreign language and the playing mode of the students.

\section{c. Evaluation of the quality of the audio and the subtitles of the game Broken Sword}

This dimension was composed by 4 items that were used to evaluate the quality of the audio and the subtitles of the Broken Sword videogame for the learning of French as a foreign language.

In the results obtained in this dimension, it was observed that the students presented an evaluation of indifference with respect to the dimension "Evaluation of the quality of audio and the subtitles of the videogame Broken Sword for the learning of French" $(\mu=3.89 ; \sigma=0.86)$.

The Student's $t$ test performed to identify possible differences related to the student's gender and the evaluation of the quality of the audio and the subtitles of the videogame Broken Sword for the learning of French as a foreign language, showed that there were no statistically significant differences.

With respect to the differences established by the student's degree and the evaluation of the audio and the subtitles of the Broken Sword videogame for the learning of French as a foreign language, the same test showed that there were no statistically significant differences.

Likewise, the ANOVA performed to verify the existence of significant differences between age, the device used to play and the playing mode, related to the evaluation of the quality of the audio and the subtitles of the Broken Sword videogame for the learning of French as a foreign language, showed that there were no significant differences related to age.

As for the influence of the device used by the users with respect to the evaluation of the quality of 
the audio and the subtitles of the Broken Sword videogame for the learning of French as a foreign language, the analysis showed that there were no significant differences.

Lastly, and referring to the playing mode, the same test was employed to compare the means. In this sense, the test showed that there were no significant differences with respect to the evaluation of the quality of the audio and the subtitles of the Broken Sword videogame for the learning of French as a foreign language and the playing mode of the students.

\section{d. Correlational Study}

In this section, the correlational study between the 3 dimensions of the questionnaire will be addressed. The data from the Pearson's correlation test, which was performed to verify the relationship between the 3 dimensions of the scale, are shown in Table 3.

\begin{tabular}{|c|c|c|c|c|}
\hline & & $\begin{array}{l}\text { Profile of the } \\
\text { student/ } \\
\text { player }\end{array}$ & $\begin{array}{l}\text { Evaluation of the } \\
\text { game for the } \\
\text { learning of } \\
\text { French }\end{array}$ & $\begin{array}{l}\text { Evaluation of the } \\
\text { quality of the audio } \\
\text { and subtitles }\end{array}$ \\
\hline \multirow{5}{*}{$\begin{array}{l}\text { Profile of the } \\
\text { student/player }\end{array}$} & Pearson's correlation & 1 & $.277^{*}$ & $.229^{*}$ \\
\hline & Sig. (two-way) & & .013 & .042 \\
\hline & $\begin{array}{l}\text { Sum of squares and } \\
\text { vector products }\end{array}$ & 91.929 & 15.693 & 16.800 \\
\hline & Covariance & 1.179 & .201 & .215 \\
\hline & $\mathrm{N}$ & 79 & 79 & 79 \\
\hline \multirow{5}{*}{$\begin{array}{l}\text { Evaluation of } \\
\text { the game for } \\
\text { the learning of } \\
\text { French }\end{array}$} & Pearson's correlation & $.277^{*}$ & 1 & $.663^{* *}$ \\
\hline & Sig. (two-way) & .013 & & .000 \\
\hline & $\begin{array}{l}\text { Sum of squares and } \\
\text { vector products }\end{array}$ & 15.693 & 34.894 & 29.993 \\
\hline & Covariance & .201 & .447 & .385 \\
\hline & $\mathrm{N}$ & 79 & 79 & 79 \\
\hline \multirow{5}{*}{$\begin{array}{l}\text { Evaluation of } \\
\text { the quality of } \\
\text { the audio and } \\
\text { subtitles }\end{array}$} & Pearson's correlation & $.229^{*}$ & $.663^{* *}$ & 1 \\
\hline & Sig. (two-way) & .042 & .000 & \\
\hline & $\begin{array}{l}\text { Sum of squares and } \\
\text { vector products }\end{array}$ & 16.800 & 29.993 & 58.585 \\
\hline & Covariance & .215 & .385 & .751 \\
\hline & $\mathrm{N}$ & 79 & 79 & 79 \\
\hline \multicolumn{5}{|c|}{ *. The correlation is significant at 0.05 (two-way) } \\
\hline \multicolumn{5}{|c|}{$* *$. The correlation is significant at 0.01 (two-way). } \\
\hline
\end{tabular}

Table 3. Results of the Two-way Correlations of the Items From the Dimension Profile of the Student/ player Found in the Questionnaire on the Use of the Videogame Broken Sword for the Teaching of French in Higher Education.

Source: Author created 
The data obtained showed that there was a relationship between dimension 1 (Profile student/ player) with dimension 2 (Evaluation of the game for the learning of French) and dimension 3 (Evaluation of the quality of audio and the subtitles of the videogame for the learning of French), respectively $(\mathrm{R}=0.277$ and $p=0.013 ; \mathrm{R}=0.229$ and $p=0.042)$, given the level of two-way significance at n.s. $=0.05$. The relationship between them is low in both cases, as pointed out by Mateo (2004) and Pérez, García, Gil and Galán (2009).

Also, it could be seen that there was a relationship between dimension 2 (Evaluation of the videogame for the learning of French) with dimension 3 (Evaluation of the quality of audio and the subtitles of the videogame for the learning of French) $(R=0.663$ and $p=0.000)$, given that there was degree of two-way significance at n.s. $=0.01$. The relationship between them is moderate, as pointed out by the previously-mentioned authors

\section{e. Explanatory models of the evaluation of the videogame Broken Sword for the learning of French}

In this section, the variable "Evaluation of the videogame Broken Sword for the learning of the French" as a function of the measurements from the dimension "profile of the student/player" will be explained through linear regressions (Pardo and Ruiz, 2002), using a step-wise method in order to observe the predictive variable (profile student/player and its relationship with the criteria variable (evaluation of the videogame for the learning of French) (see table 4).

\begin{tabular}{|c|c|c|c|c|c|c|c|c|}
\hline \multirow{2}{*}{\multicolumn{2}{|c|}{ Model }} & \multicolumn{2}{|c|}{$\begin{array}{l}\text { Non-standardized } \\
\text { coefficients }\end{array}$} & \multirow{3}{*}{$\begin{array}{l}\text { Standardized } \\
\text { coefficients } \\
\text { Beta } \\
\end{array}$} & \multirow{3}{*}{$\begin{array}{l}\mathrm{t} \\
18.080\end{array}$} & \multirow{3}{*}{$\begin{array}{l}\text { Sig. } \\
\\
.000\end{array}$} & \multicolumn{2}{|c|}{$\begin{array}{l}\text { Co- I i n e a rit y } \\
\text { statistics }\end{array}$} \\
\hline & & \multirow{2}{*}{$\begin{array}{l}\text { B } \\
3.012 \\
\end{array}$} & \multirow{2}{*}{$\begin{array}{l}\begin{array}{l}\text { Standar } \\
\mathrm{d} \text { error }\end{array} \\
.167 \\
\end{array}$} & & & & \multirow{2}{*}{ Tolerance } & \multirow[t]{2}{*}{ VIF } \\
\hline 1 & (Constant) & & & & & & & \\
\hline & $\begin{array}{l}\text { Profile student/ } \\
\text { player }\end{array}$ & .171 & .067 & .277 & 2.530 & .013 & 1.000 & 1.000 \\
\hline
\end{tabular}

Table 4Coefficients of the Regression Line for the Dependent Variable "Evaluation of the Videogame Broken Sword for the Teaching of French in Higher Education" as a function of the Measurements from the Dimension "Profile student/player".

Source: Author created

The results obtained, as observed in table 4, allowed us to observe that the dimension "Profile student/player" was a predictive factor of the dimension "Evaluation of the videogame Broken Sword in the learning of French. As $\beta=.27, \mathrm{t}(027)=2.53$ and $p<.05$, the result was statistically significant, so that the hypothesis of the linear relationship between the profile of the student/ player and the evaluation of the videogame Broken Sword was accepted. However, the $\mathrm{R}^{2}$ value was .06, indicating that a very low percentage $(6 \%)$ of the variability of the evaluation of this videogame in the learning of French was explained by the profile student/player.

\section{Conclusions and discussion}

After conducting our study, it can be generally concluded that the habit of using videogames in an adult university population in the Humanities field is very low, which can be an exception, or simply shows that its general, real use was less that what was originally assumed. However, it should be mentioned that the men had a greater habit and preference for videogames, while most of the women did not have either the habit or the preference. 
In spite of this, we considered the results to be very positive, as for many of the students this exercise was not only a test with a language that they did not master yet, but also had technical difficulties that they had to overcome. In this sense, all the students were able to advance in the videogame during the 5 hours it was played, although this progress was not evaluated in order to avoid a greater "didactization" of the experience.

On the other hand, the fact that the videogame was a commercial game, and thus not adapted according to different levels of language mastery, and not accompanied by tools that could have eased its use, was a gamble that was part of our methodological proposal of learning autonomy. However, once again, this autonomy has not been achieved in the learning of languages, as the student did not become truly involved in the practice itself, as he or she did not use all the means that could be provided by the game platform, chats, dictionary, etc.

Unlike other types of linguistic inputs, videogames - whether more or less realistic or attractive, always involve a challenge for the player, who has to understand and think about what he hears or reads to continue playing. Understanding is crucial in order to pass levels and win. It consists of a linguistic input exercise which requires the player to pay lot of attention and to make a deep analysis of the referential meaning of words.

BrokenSword is equipped with authentic videogames texts, with all the advantages and challenges that this involves. Therefore, we believe it is extremely useful from a communicative point of view. Understanding its dialogues, audio, texts and subtitles has been challenging for students, who had to make use of dictionaries; however, those who persevered, as they explained in their feedbacks in class, became hooked on the game.

Also, the environment created in the class groups should be highlighted, as these implied real help and collaboration, with those students who already knew the Steam platform and the point \& click type of games playing the main role.

As for the teachers, it was a complete challenge for them, and this experience invited them to continue along this line. More specifically, it encouraged them to incorporate, in a habitual manner, the videogame as another resource with which to teach/learn a language. Having said this, it should be mentioned that at the institutional level, videogames are not considered didactic material, so that their acquisition with normal institutional budgets is not an easy task, and the projects related to them have yet to reach the scientific interest as other projects with other types of materials.

Ultimately, if serial novels are considered to be banal reading for domestic workers, and as comic books are prohibited to children as they are considered to be poor reading, it is known that in the world of videogames, some are high-quality products, and therefore, should form part of university training.

\section{References}

Alabay, S. (2015). Enseignement / apprentissage du fle avec les jeux vidéo. Univ. Européenne.

Autores (2018). El uso de videojuegos serios en el aprendizaje de francés en educación superior. Revista Mexicana de Investigación Educativa, 76, 157-177.

Beacco, J. C. (1988). Documents pour la classe: quels critères? Le Français dans le Monde, 214, 46-49.

Beacco, J. C. (2000). Les dimensions culturelles des enseignements de langue. Collection "F/Références". Paris: Hachette.

Bérard, E. (1991). L'approche communicative. Paris: CLE Int.

Berns, A., González-Pardo, A., \& Camacho, D. (2011). Designing videogames for foreign language learning. Milan: Simonelli Editore. 
Berns, A., González-Pardo, A., \& Camacho, D. (2013). Game-like language learning in 3-D virtual environments. Computers \& Education an International Journal, 60, 210-220.

Besse, H. (1984). Sur quelques aspects culturels et métalinguistiques de la compréhension d'un document en classe de langue. Tranel, 6, 135-145.

Besse, H. (1987). Documents authentiques et enseignement/apprentissage de la grammaire d'une LE. In J. Cortés et al., Une introduction à la recherche scientifique en didactique des langues, 181-215. Paris: Didier.

Calvo-Ferrer, J. R., \& Belda-Medina, J. R. (2015). Análisis de la satisfacción del alumnado de L2 con respecto a la adquisición de terminología especializada por medio de videojuegos: estudio de caso. Porta Linguarum, 24, 179-190.

Cuenca, A., \& Lozano, S. (2016). La enseñanza de la investigación. Diálogo entre la teoría y el oficio del investigador en Trabajo Social. La Plata: Editorial de la Universidad Nacional de La Plata (EDULP).

Del Moral, M. E., \& Fernández, L. C. (2015). Videojuegos en las aulas: implicaciones de una innovación disruptiva para desarrollar las Inteligencias Múltiples. Revista Complutense de Educación, 26, 97-118.

García-Carbonell, A., \& Watts, F. (2007). Perspectiva histórica de la simulación y juego como estrategia docente: de la guerra al aula de lenguas. Ibérica, 13, 65-84.

García-Carbonell, A., Andreu-Andrés, M. A., \& Watts, F. (2014). Simulation and Gaming as the Future's Language of Language Learning and Acquisition of Professional Competences. In Back to the Future of Gaming, 214-227. Alemania: WB Verlag.

Gilmore, A. (2007). Authentic materials and authenticity in foreign language learning. Language Teaching, 40, 97-118.

Godwin-Jones, R. (2014). Games in language learning: Opportunities and Challenges. Language Learning \& Technology, 18, 9-19.

Klein, A. (2013). 3 Reasons why video games are underestimated in language learning. Blog (online). URI: https://learnoutlive.com/3-reasons-why-games-are-great-for-language-learning/

Lorenzo-Seva, U. (2000). The weighted oblimin rotation. Psychometrika, 65, 301-318.

Lorenzo-Seva, U., \& Van Ginkel, J. R. (2016). Multiple Imputation of missing values in exploratory factor analysis of multidimensional scales: estimating latent trait scores. Anales de Psicología, 32, 596-608.

Mateo, J. (2004). La investigación 'ex post-facto'. In R. Bisquerra, (coord.), Metodología de investigación educativa, 196-230. Madrid: La Muralla,

Merino-Soto, C. (2016). Diferencias entre coeficientes alfa de Cronbach, con muestras y partes pequeñas: Un programa VB. Anales de Psicología, 32, 587-588.

Pardo, A., \& Ruíz, M. (2002). SPSS 11: Guía para el análisis de datos. Madrid: MCGRAW-HILL.

Pérez, R.; García, J.L.; Gil, J.A., \& Galán, A. (2009). Estadística aplicada a la Educación. Madrid: Pearson Prentice Hall.

Rama, P. S., Black, R. W., Van Es, E., \& Warschauer, M. (2012). Affordances for second language learning in World of Warcraft. ReCALL, 24, 322-338.

Ricoy, C., \& Ameneiros, A. (2016). Preferencias, dedicación y problemáticas generadas por los videojuegos: Una perspectiva de género. Revista Complutense de Educación, 27, 1291-1308.

Wouters, P., Van Nimwegen, C., Van Oostendorp, H., \& Van Der Spek, E. D. (2013). "A Meta-Analysis of the Cognitive and Motivational Effects of Serious Games". Journal of Educational Psychology, 105, 249-265.

Quivy, M., \& Tardieu, C. (2002). Glossaire de didactique de I'anglais. Paris: Ellipses. 